Prace Literackie LVIII

Wrocław 2018

https://doi.org/10.19195/0079-4767.58.26

\author{
GABRIELA IWIŃSKA \\ ORCID: 0000-0001-7151-9350 \\ Uniwersytet Wrocławski
}

\title{
Próba własnej filozofii we Wszystko jest poezja Edwarda Stachury
}

„Wszystko jest poezją, a najmniej poezją jest napisany wiersz; każdy jest

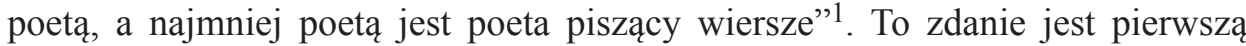
i najważniejszą minidefinicją świata tworzoną przez Edwarda Stachurę, a także jednym z wielu rozwinięć myśli „wszystko jest poezja”. Wprowadza nas ono w szczególny rodzaj odbierania rzeczywistości — przez pryzmat poezji. W tak ustawionej perspektywie pojęcia „poeta” oraz „poezja” nie tyle zmieniają swoje znaczenie, ile je rozszerzają. W ten sposób poetą staje się człowiek tworzący po prostu coś pięknego. I nie muszą to być, według tej teorii, wiersze. Wprost przeciwnie: ten, który zajmuje się pisaniem tekstów literackich, jest poetą najmniej. Podobnie niewiele poezji jest w samym tekście, ponieważ wiersz jest gdzieś dalej, może być moim krzesłem, długopisem, wypowiedzianym przez kogoś „dzień dobry". Te początkowe rozważania sprowadzają się do jednego pytania: gdzie szukać prawdziwej poezji i prawdziwego poety?

poezja nie jest sztuką w tym sensie, jak sztuką jest sztuka pisania wierszy, sztuka malowania obrazów, sztuka komponowania utworów muzycznych i tym podobne. To znaczy, ponieważ wszystko jest poezją, to i sztuka jest poezją, ale jest [ta — przyp. G.I.] sztuka [...] tylko jedną z tysiącliczebnych składowych poezji [...]. Wszystko składa się na poezję, ale poezja jest wszystkim. Czyli wszystko jest poezją, ale to poezja jest wszystkim ${ }^{2}$.

Poezja jest sztuką, która kojarzy się w pierwszym odruchu z malarstwem, literaturą czy muzyką, ale tworzy ona, jak dowodzi Stachura, najmniejszą część poezji. Sztuką jest bowiem chodzenie po polach, wysiadanie z pociągu, siedzenie nad rzeką, jedzenie kilograma czereśni, zakupienie tomiku, wymieniane między

${ }^{1}$ E. Stachura, Wszystko jest poezja. Opowieść-rzeka, red. H. Bereza, Z. Fedecki, K. Rutkowski, t. 4, Warszawa 1984, s. 5.

2 Ibidem, s. 21. 
innymi przez autora. Poezja jest tym wszystkim, co staramy się dostrzegać i opisywać. Ta myśl staje się bardziej zrozumiała, gdy ją Stachura rozwija:

Tak więc dużo bardziej niż czymś innym, niż na przykład pisaniem wierszy, poezja jest sposobem bycia, sposobem życia, sposobem innego, drugiego życia. Dużo bardziej niż czymś innym poezja jest sposobem włączenia tego pierwszego życia, całkiem fałszywego lub ćwierćprawdziwego, lub co najwyżej półprawdziwego, w drugie, prawdziwe życie. Tym właśnie: przemianą tego pierwszego życia w drugie życie ja się od pewnego czasu bez reszty zajmuję ${ }^{3}$.

W tym fragmencie Stachura literalnie wykłada, czym dla niego jest poezja - sposobem bycia. Ktoś mógłby zwrócić uwagę na niekonsekwencję autora: punktem wyjścia jest fraza „wszystko jest poezja”, później poezja definiowana jest jako rodzaj sztuki, a teraz zostaje skonkretyzowana jako życie prawdziwe. Jedyna odpowiedź, jaka $\mathrm{w}$ tej chwili się nasuwa, może wydać się banalna, ale trafna ze względu na słowa samego Stachury: poezja jest tym wszystkim naraz. Skoro poezja jest sposobem bycia, trzeba więc się zatroszczyć, by ta poezja była tą najlepszą.

Idąc dalej, można założyć, że człowiek według Stachurowej filozofii jest zarówno poetą, jak i wierszem wobec siebie. Poetą, ponieważ jest odpowiedzialny za własny sposób bycia, swoje zachowanie, charakter, osobowość. To zaś, jak żyje, jest „tekstem” podlegającym opinii własnej, jak też otaczającego środowiska. Nie ma więc w tym nic dziwnego, gdy pielęgniarka opisana we Wszystko jest poezja przez Stachurę zostaje nazwana grafomanką, z powodu braku empatii i niefachowej opieki nad nim jako pacjentem w szpitalu. Kobieta jednak nie musi być skazana na wieczne bycie grafomanką. Może swój wiersz (siebie) ulepszyć, a więc zmienić zachowanie, nastawienie do wykonywanej pracy, do ludzi.

Problem interpretacyjny, który się pojawia, dotyczy kwestii przemiany jednego życia w drugie, o jakiej Stachura wspomina. O ile można się domyślić, że to fałszywe życie, a w najlepszym wypadku półprawdziwe, mogłoby być tym codziennym, rutynowym, w którym nie ma miejsca na refleksję, to to drugie, „prawdziwe” życie pozostaje raczej domysłem. Na podstawie tego, co zostało już wcześniej powiedziane, można wykluczyć, by tworzenie bądź czytanie poezji było sposobem na prawdziwe życie. Niemniej jednak o jakiś rodzaj poezji chodzi, jeszcze do końca niesprecyzowany. Stachura nie daje żadnych określonych etycznych wskazówek, by odbiorca mógł wiedzieć, jak postępować. Co zrobić, żeby stać się najlepszą poezją? Leszek Bugajski tak interpretował zagadnienie prawdziwego życia:

I tą przemianą zajmuje się narrator najnowszej książki Stachury: on po prostu żyje i to życie jest wartością samą w sobie, życie swobodne, otwarte na wszystko, co przynieść może i nie może świat, życie w każdym calu pełne, bo zawierające w sobie równocześnie wysublimowane porywy intelektu i rozkosz fizycznego zmęczenia, prostotę i swobodną włóczęgę po bez mała całym świecie ${ }^{4}$.

\footnotetext{
${ }^{3}$ Ibidem, s. 22.

${ }^{4}$ L. Bugajski, Poezja wedtug Stachury, „Twórczość” 1976, nr 6, s. 95.
} 
Na podstawie tych słów mogłoby się wydawać, że sposób na prawdziwe życie znajduje się w życiorysie samego Stachury, a więc definicją poezji byłby sam autor. Nie tyle jego twórczość, ile to, jakim był człowiekiem. Zostawiam ten wątek otwarty. Być może dalsze definicje pojęć poezji i poety dookreślą, czym jest owo prawdziwe życie.

Stachura mówi „wszystko jest poezją" i doskonale zdaje sobie sprawę, że powiedzieć „wszystko”, to według niektórych mało powiedzieć. „Wszystko” więc u autora wcale nie jest pojęciem „wolnym”, czyli takim, które nie ma żadnych ograniczeń, choćby tak się na początku wydawało. Ma wyraźne granice i warunki. Wskazując palcem na jakikolwiek przedmiot lub na jakąkolwiek osobę, nie mogę ich nazwać poezją? We „wszystkim” istnieją ścisłe paradygmaty — negatywne i pozytywne. Stachura używa tych dychotomicznych pojęć w odniesieniu do świata, do przenikania się dwóch różnych światów. Pisze to w kontekście nieuchwytności miejsca, gdzie kończy się mrok, a zaczyna jasność:

Tylko jest przenikanie się. Prawie że niewidoczne, choć jednak trochę widoczne. A ile światów wzajemnie się przenika w sposób absolutnie dla tych światów niewidoczny, niezauważalny, wprost niedotykalny? Świat żywych i świat zmarłych? Świat planety Ziemi i świat na przykład z konstelacji Lutni gwiazdy Wega — przyjaciółki romantyków, jak mówi astronom z Lubicza? Świat z tej strony lustra i świat z tamtej strony lustra? Świat „pozytywny” i świat „negatywny”? Podobno jest możliwość istnienia świata negatywnego. Jądro może być minusowe, elektron dodatni - i nic się nie zmieni ${ }^{5}$.

Ta metafora też idealnie pasuje do istnienia dwóch równoległych poezji, dobrej i złej. To znaczy, jeśli pójdę do księgarni, to będzie to poezja, jeśli zaś wyrzucę książki do kosza, też będzie to poezja. Różnica polega na tym, że pierwszy przykład to właśnie poezja pozytywna, a drugi - poezja negatywna, czyli grafomańska. W tym wszystkim Stachura umieszcza siebie, poetę, który kontroluje niejako „wiersze” w świecie, unaocznia ich błędy bądź wskazuje te wybitne, samemu starając się tworzyć właściwą poezję, jak też przemieniać złą „twórczość” w, chociażby, poprawną. Rola poety sprowadza się do właściwego postępowania względem siebie i otoczenia, a także do rozpoznawania tego, co „dobre” w codzienności, oraz do otwierania drugiego świata, który jest prawdziwym i realnym byciem. Byciem w poezji i dzięki poezji.

Z psychologicznego punktu widzenia tworzenie jest funkcją terapeutyczną. Tak też do pisania podchodzi Stachura. I oczywiście chodzi tu nie tyle o poezję pisaną, ile pozatekstową,

o której powiem, że jest wyobraźnią wyobrażoną, zjawą jak najbardziej realną, dotykalną, namacalną; o której powiem, że jest poezją nie teoretyczną już, ale wreszcie praktyczną; poezją, za której sprawą samotność przestaje być panicznym strachem przed samotnością, nie ma już samotności ${ }^{6}$.

\footnotetext{
${ }^{5}$ E. Stachura, op. cit., s. 211.

${ }^{6}$ Ibidem.
} 
To, co pozwala wynurzyć się z samotności, z przygnębienia, nie jest lekturą tekstu literackiego, lecz uświadomieniem sobie świata jako poezji, przyjęciem otoczenia jako czegoś potencjalnie pięknego i prawdziwego. Stachura dokonuje pewnego rodzaju ożywienia poezji, tak jakby tekst mógł powstać z kartki i egzystować jako istota realna. Sądzę, że autor traktuje poezję jako przyjaciela, przy którym nie odczuwa samotności, dlatego pisze o wymiarze praktycznym poezji, nie zaś teoretycznym. Ta praktyczność tekstu musi mieć stały związek z rzeczywistością, logiczny i jednocześnie emocjonalny do tego stopnia, by mogło się zdawać, że jest naprawdę. Dobrym przykładem rozumowania Stachury jest fragment z Siekierezady:

Kiedy obudziłem się, rano było. Jasny dzień. Położyłem się wieczorem i obudziłem się rano. Co powiedziałem? Położyłem się wieczorem i obudziłem się rano. Tak powiedziałem. [...] Przecież to jest jedno z najpiękniejszych zdań świata, to jest olśniewające, to jest snop światła w same oczy, w same usta. Jak mogłem tego przedtem nie zauważyć? Ile razy wypowiedziałem to zwyczajne proste zdanie, nie zdając sobie sprawy, nie widząc, ślepy, że to jest przecież cud, opisanie cudu ${ }^{7}$.

Skutkiem terapii poezją jest nieodczuwanie lęku przed fałszem i obłudą. W ogóle ich się nie zakłada, a więc można sobie wyobrazić, że przebywanie w jakimkolwiek otoczeniu czy wyjście na spacer może już być uznane za „lek”, środek znieczulający ból. W tym fragmencie pisarz docenia bardzo prostą czynność, mianowicie położenie się do snu i wybudzenie z niego. Cud można równie dobrze zamienić na synonimiczną w tym wypadku poezję. „Dzięki poezji. POEZJI WZAJEMNOŚCI"8. Stachura zostawia to stwierdzenie nieco w zawieszeniu, bo na następnych stronach można przeczytać:

$\mathrm{O}$, wzajemność poezji to nie są udane próby napisania pięknych czy nawet przepięknych wierszy, kiedy wygląda na to, że te właśnie piękne wiersze są tą właśnie uzyskaną wzajemnością poezji. [...] O, wzajemność poezji to jest coś dużo więcej niż dokonania artystyczne9

Trudno powiedzieć, czym jest owa wzajemność poezji. Można na pewno powiedzieć, czym wzajemność poezji nie jest — nie jest tekstem poetyckim, który jest udany, który działa, trafia do czytelnika, nawet tak wymagającego jak, powiedzmy, krytyk literacki. Wzajemność poezji nie polega na tym, że dany wiersz się docenia, bo nie o wiersz w ogóle chodzi. To coś więcej niż dokonania artystyczne. Czym jest to „coś więcej niż dokonania artystyczne”?

Nie odpowiadając na razie na to pytanie, dokładam jeszcze kolejną definicję poezji, która jest darem absolutnym. Absolutny to zupełny, niekwestionowany, istniejący obiektywnie, oparty na zasadach absolutyzmu lub rządzący według tych zasad ${ }^{10}$. Poezja więc jest darem, ponieważ Stachura tak mówi, tak przyjął. Jest darem niepodważalnym, który albo zaakceptujemy, uznamy, albo nie. Da-

\footnotetext{
${ }^{7}$ E. Stachura, Siekierezada, Torun 2011, s. 45-46.

${ }^{8}$ Ibidem, s. 43 (zachowany układ według książki).

9 Ibidem, s. 53.

${ }^{10} \mathrm{http}: / /$ sjp.pwn.pl/szukaj/absolutny.html [dostęp: 5.02.2018].
} 
rem opartym na cesze prawdziwości w teorii poznania ${ }^{11}$. Gdy Stachura pisze, że „nadeszła CHWILA DARU ABSOLUTNEGO”12, to chce powiedzieć, że on ustanowił świat jako poezję. Krzysztof Rutkowski trafnie to interpretował: „Rzeczywistością jest dopiero całościowe odczucie świata, jego uintensywniany i przywoływany w każdej sekundzie obraz"13. Skoro pisarz uważa poezję za dar, to znaczy, że w tym rozumieniu powinno się odbierać świat jako pewnego rodzaju prezent, który może trwać nieskończenie. Jako ofiara składana przez poetę odbiorcom. Dar powiązany jest z zachwytem - a ten jest niewyczerpalny, dlatego że to, co świat ma nam do oddania, stanowi składnik niewyczerpalny. Tutaj Stachura podaje przykłady źdźbła trawy, piwnych oczu, konstelacji gwiazd. Dar jest nieskończony, ponieważ zachwyt jest nieskończony.

Czy idea daru absolutnego wyjaśnia wzajemność poezji? Jednak nie do końca. Można to odczytywać w taki sposób - Stachura jako poeta jest zarówno twórcą, jak i kreatorem świata będącego poezją. Każdy jego składnik odbiera z zachwytem, który trwa nieskończenie. Zdaje się, że wolno również to wszystko odczytywać jako przenikanie świata do poezji i poezji do świata. Mówi: „Na co popatrzyłem, wszystko było poezją. Bo ja tak chciałem. Wszystko jest poezją, tam gdzie jest poeta"14, co byłoby potwierdzeniem mojej eksplikacji. W każdym razie, skoro Stachura w taki sposób tworzy świat, oczekuje więc, że ten świat mu się zwróci, odpłaci mu dobrem, pięknem i wszechobecną prawdą. Ale poezja, jak się okazuje, nie zawsze jest wzajemna - wątpliwości nachodzą autora na przykład, gdy dopuszcza do siebie myśl o śmierci. Stachura pisze o tym tuż obok fragmentu o wzajemności i darze absolutnym:

Na co popatrzyłem, wszystko było poezją, zwłaszcza przelatujące raz po raz za oknem pociągi, w których mnie nie było, w żadnym z nich; na co popatrzyłem — chciało mi się płakać. Niestety nie czułem wzajemności poezji [wyr. — G.I.], choć tak bardzo tego potrzebowałem. Tylko $\operatorname{strach}^{15}$.

To wcale nie koniec:

potem zezłościłem się, tak, zezłościłem się: na poezję, na wszystko; jeżeli mnie nie będzie, ty głupia poezjo, ty głupi świecie, ty głupie wszystko, to kto tak jak ja was doceni, kto tak jak ja was będzie oddychał i czkał od zachłystywania się wami? ${ }^{16}$

Uważam, że jest to podstawowy punkt mówienia o poezji wszystkiego w całej filozofii Stachurowej i w ogóle punkt w kontekście osoby Edwarda Stachury. Jego filozofia w swoim zamiarze jest czysto idealistyczna, a nawet idylliczna i wskazuje na to choćby słówko „wszystko” czy „absolutny”. Nie tylko ja tak odbieram jego osobo-

${ }^{11}$ Według pojęcia absolutyzm http://encyklopedia.pwn.pl/haslo/absolutyzm;3865278.html [dostęp: 5.02.2018].

12 E. Stachura, Wszystko jest poezja, s. 49.

${ }^{13}$ K. Rutkowski, Próba całości i poezja świata, „Literatura” 1976, nr 19, s. 12.

14 E. Stachura, Wszystko jest poezja, s. 55.

15 Ibidem, s. 57.

${ }^{16}$ Ibidem. 
wość: Marian Buchowski opisuje go jako maksymalistę, Barbara Czochralska jako osobę poszukującą absolutu ${ }^{17}$, natomiast Dariusz Pachocki w tytule swojej książki poświęconej analizie jego twórczości umieścił określenie „Stachura totalny”"

Czy gdyby Stachura się nie wydarzył, poezja nie byłaby wszystkim? Bez Stachury wszystko nie jest już poezją? Można przecież tak powiedzieć. Myślenie Stachury często łączone jest z filozofią egzystencjalizmu, jak napisałam na początku, ale zastanawiam się jednak, czy nie jest to nadużycie, które pozwala teksty poety trochę łatwiej sklasyfikować. Owszem, Stachura skupiał się na własnej jednostkowości, swoim doświadczeniu, stąd właśnie wyprowadził tezę o wszystkości poezji. Zaintrygował mnie również fragment z Kierkegaarda: „wiara właśnie tam się zaczyna, gdzie myślenie się kończy"19. Zgadza się to z punktem widzenia Stachury, który powtarza, że nie wierzy w swoją śmierć. Patrząc racjonalnie, to taki wniosek wydaje się nielogiczny, każdy wie, że jest jakiś „koniec”. Stachura jest skupiony na własnej jednostkowości. Niemożliwe dla niego jest ot tak zniknąć z tego świata. Samo sformułowanie „wszystko jest poezja” to kwestia wiary. Koncepcja poety-człowieka w świecie Stachury znajduje analogię w myśli Heideggera:

Człowiek-w-świecie, mechanicznie spełniający swe czynności, przestaje być sobą samym. Bezosobowe stają się też relacje między ludźmi - codzienna, bezmyślna krzątanina odbiera każdemu to, co naprawdę jego. Heidegger określa ten stan upadaniem — upadaniem w Się. [...] Się oddala człowieka od bycia, choć jest właśnie byciem ludzkim, istotnym przejawem egzystencji. Ale ponieważ bycie-w-świecie wiąże się z upadaniem w Się, i zapominaniem o byciu, Heidegger mówi, że człowiek jest rzucony, rzucony-w-świat ${ }^{20}$.

Kojarzymy owo „się” oczywiście z późniejszymi dziełami Stachury, niemniej zarysowuje się tu coś, co jest istotne u niego od samego początku: fakt, że to poeta został rzucony w świat, w nim się szamocze i, by próbować się uwolnić od niepokojów i mgieł, wymyślił apoteozę świata opartą na wszystkości poezji. Późniejsze świadectwo twórcze Stachury podważy bliskość tej filozofii wtedy, kiedy pojawi się człowiek-nikt. Człowiek-nikt przeciwstawi się wcześniejszemu egzystencjalnemu człowiekowi-ja: „Egzystencjalista, przeciwnie: będąc przywiązanym do swego »ja«, nieuchronnie doświadczać musi cierpienia, które z racjonalnego punktu widzenia nie daje się przekroczyć" ${ }^{21}$. Człowiek-nikt będzie wyzwolony od tego typu udręk i cierpieć Stachurze będzie zabraniał, choć wiadomo, że ostatecznie przegra.

Pisać „wszystko jest poezja” to objąć, przytulić i przyciągnąć do siebie całość, na jaką składa się każda, choćby najmniejsza rzecz, która jest. To chcieć

${ }^{17}$ M. Buchowski, op. cit., s. 401.

18 D. Pachocki, Stachura totalny, Lublin 2007.

19 S. Kierkegaard, Bojaźń i drżenie, przeł. J. Iwaszkiewicz, Warszawa 1982, s. 55.

${ }^{20}$ W. Szydłowska, Egzystencja, egzystencja-lizm, egzystencja-liści, [w:] eadem, Egzystencja-lizm w kontekstach polskich. Szkic o doświadczeniu, myśleniu i pisaniu powojennym, Warszawa 1997, s. 26.

${ }^{21}$ M. Januszkiewicz, Od egzystencjalizmu do mistyki. O prozie Edwarda Stachury, „Pamiętnik Literacki" 1994, nr 4, s. 98. 
widzieć całość, nawet jeśli patrzy się na drugiego człowieka czy na polną ścieżkę. Także: współtworzyć całość. Być doskonałością. „Przypomina to trochę witkiewiczowską »wielość w jedności«, nie ograniczoną czasem i przestrzenią tożsamość z światem, każdą jego częścią i całością równocześnie"22. Przytoczone bezokoliczniki (objąć, przytulić, przyciągnąć, współtworzyć) znaczą też - poświęcić się. Bardzo zgrabnie nazywa ten stan Dariusz Pachocki, że jest to „zamach na wszystkość" 23. Zauważa, że w tytule prawie każdego utworu zawarta jest owa wszystkość lub jej synonimy (Wszystko jest poezja, Dużo ognia, Cała jaskrawość), a jeśli nie synonim, to zamiar formy o ładunku wszystkiego (Fabula rasa, Się $)^{24}$. Pachocki nazywa to programem, dla mnie to lekka nadinterpretacja. Przynajmniej za dużo o jeden z sensów tego stwierdzenia. To raczej przeczucie niż koncept. Immanentna potrzeba komunikowania się z „,wszystkim” z wykorzystaniem literatury, wynikająca bardziej ze złożonej osobowości Stachury aniżeli z konkretnego planu. Niemniej ktoś, kto powtarza tę samą zasadę w każdym ze swoich dzieł, musi być świadom wierności, jakiej dochowuje swojej podstawowej zasadzie oraz temu, co się z nią wiąże. Bo nawet w Fabula rasa, choć w tym dziele Stachura podchodzi do „wszystkości” bardziej restrykcyjnie i z dystansu, to o niej nie zapomina. Tak to ujął Maciej Szybist:

Stachura głosi całkiem konkretną i sformułowaną filozofię. Nie jest ona co prawda określona w szczegółach i nie jest wyrażona w języku naukowym, ale posiada wszystkie cechy systemu filozoficznego. Dąży mianowicie do objęcia całości, do zunifikowania w jednej formule całości znanego kosmosu, jest próbą umiejscowienia człowieka w tym świecie i nakreślenia jego stosunków z innymi ludźmi, dąży wreszcie do wytyczenia zasad postępowania w świecie, dając zarys programu postępowania, który jest zarówno postulatem moralnym, jak i próbą opisu sytuacji ludzkiej ${ }^{25}$.

Wrażliwość, a w wypadku Stachury nadwrażliwość, może ulec również wielu naciskom natury. I ulegała im. Stachura jakby „ofiarował” siebie i swoje miejsce w literaturze temu, co widział, co zostało stworzone. Kiedy wypowiadał „wszystko jest poezją, a najmniej poezją jest napisany wiersz”, to wynosił te choćby najmniejsze istnienia na piedestał. Świetnie pokazuje to w Missa Pagana, a najlepiej w wierszu Sanctus:

Święty kurz na drodze

Święty kij przy nodze

Święte krople potu

Święte wędrowanie

Święty kamień w polu

Przysiądź na nim, panie

Święty płomyk rosy

Święta święta święta-ziemia co nas nosi ${ }^{26}$.

${ }^{22}$ K. Grela, Wszystko jest poezja, „Radar” 1982, nr 14, s. 15.

${ }^{23}$ D. Pachocki, op. cit., s. 29.

${ }^{24}$ Ibidem, s. 31.

${ }^{25}$ M. Szybist, Uśmiechnięty Dostojewski, „Życie Literackie” 1970, nr 6, s. 6.

${ }^{26}$ E. Stachura, Wiersze, Toruń 2002, s. 124. 
Poeta wywracał hierarchię zastaną, oddawał hołd najmniejszym cząstkom ziemi, które się zazwyczaj pomija. Reprezentował naturę, użyczał jej głosu w swoich książkach. Może z tej racji choćby, że „przypomniało mi się to, co czasami bezwiednie zapomniałem, a co wpajałem sobie od lat twardo i tak jak trzeba: że każdy dzień jest dniem ostatnim"27. Stachura pozwalał naturze zająć w sobie miejsce, przez co wiele razy przez niego przemawiała. Jego postawa wobec natury nie ograniczała się tylko do roli biernego medium.

A jednak świat w perspektywie poezji nie zdołał wyzwolić go od obłędu, nie uchronił przed (samo)zagładą. Owa percepcja, najczulsza z możliwych, okazała się niewystarczająca i nie zdołała powstrzymać Stachury przed ostatecznym. Po pierwszej samobójczej próbie, po wypadku pod Bednarami, po utracie prawej ręki w wyniku rzucenia się pod nadjeżdżający elektrowóz, Stachura odzyskał przytomność umysłu, a wręcz zyskał świadomość sił, jakie go za sobą pociągnęły:

Byłem buntownikiem łagodnym, najłagodniejszym z możliwych, ale krańcowym. Poszedłem do końca. Czy za daleko? Chciałem unieść wszystkie nieszczęścia świata ludzi. I zwariowałem. Ale czy od tego? Nie wiem. Teraz a nim buntownik, a nim pogodzony ze światem. Chciałbym pogodzić się ze światem, bo los mój jest nie do zniesienia. Garnę się do ludzi, szukając u nich ulgi i jakiegoś ratunku. Nie wiem, w którym miejscu popełniłem błąd, jeżeli go popełniłem ${ }^{28}$.

Można to określić jako postawę szaleńca, który chciał zbawić świat i ludzi, ukazując, że „wszystko jest poezja” i że „każdy jest poetą”. Pokazywał rzeczywistość z bliska, sam ją badał, oceniał i zadawał jej pytania, te najprostsze. Odbierał realność jako tekst, jako wiersz, który stale podlega interpretacji i analizie. „On tkwi w nie-literaturze i tylko czasem »przyplątuje się« mu literatura"29.

Stosował język oddający, w jego mniemaniu, w najlepszy sposób istotę własnej filozofii języka:

Minęło kilka dni, jak piszą powieściopisarze. I tak to jednym zdaniem załatwiają się z kilkoma dniami, których to dni, jakiekolwiek by one były, bezbarwne, puste, bezmiłosne, jeśli to jest w ogóle możliwe, nie można załatwić jednym zdaniem, jednym pociągnięciem, drobnym ruchem ręki, lekkim wdzięcznym gestem [...]. Ale mnie przynajmniej śmieszy takie zdanie: minęło kilka dni. Nie mówiąc o tym, że boli mnie to, ubliża mi straszliwie. Bo to tak wygląda, że, ot, minęło kilka dni. Jakby nigdy nic ${ }^{30}$.

Ten fragment podsumowuje znaną frazę ,wszystko jest poezja”. Słowa te powinno się traktować właśnie jako filozofię rozumianą nie w kategoriach systemu, lecz jako sposób na życie i na traktowanie literatury. Poezja to coś więcej niż tekst literacki, a „wszystko” to coś więcej niż uogólnienie. Słusznie można posądzić Stachurę o stawianie się na równi z Jezusem, którego miłosierdzie było nieskończone. Autor przyjął dość podobną rolę w swoim mniemaniu i efektem tego jest to zdanie. „Wszystko jest poezja” to wyświęcenie otaczającego świata, wszystkiego,

27 E. Stachura, Cała jaskrawość, Toruń 2012, s. 23.

28 Słowa Edwarda Stachury przytoczone za M. Buchowski, op. cit., s. 542.

${ }^{29}$ L. Bugajski, op. cit., s. 96.

${ }^{30}$ E. Stachura, Siekierezada, s. 59. 
co się z nim wiąże oraz ludzi — chociaż z tym niejednokrotnie bywa trudniej. Kiedy się wie, co ta fraza oznacza, inaczej odczytuje się twórczość Stachury. Pełniej. Poeta pisał emocjami, wrażliwością i bogatym doświadczeniem codziennego dnia. I to „wszystko” jest najważniejsze. Ważniejsze niż sam Stachura. Poezja w tym kontekście jest pewną formą raju, do której można się uciec i, jak autor, nie być już samemu. Literatura zatem to terapia na wszelkie bolączki, ale tylko gdy spojrzymy na nią przez pryzmat rzeczywistości. Tego, że literatura jest mostem do prawdziwego świata i odwrotnie. Dlatego to „życiopisanie” poety, mieszanie codzienności z pisaniem. „Wszystko jest poezja” to fraza i przykazanie, które postawił Edward Stachura ludziom, a przede wszystkim sobie.

\section{Bibliografia}

\section{Literatura podmiotu}

Stachura E., Cała jaskrawość, Toruń 2012.

Stachura E., Siekierezada, Toruń 2011.

Stachura E., Wiersze, Toruń 2002.

Stachura E., Wszystko jest poezja. Opowieść-rzeka, red. H. Bereza, Z. Fedecki, K. Rutkowski, t. 4, Warszawa 1984.

\section{Literatura przedmiotu}

Wydawnictwa zwarte

Buchowski M., Buty Ikara, Warszawa 2014.

Kierkegaard S., Bojaźń i drżenie, przeł. J. Iwaszkiewicz, Warszawa 1982.

Pachocki D., Stachura totalny, Lublin 2007.

Szydłowska W., Egzystencja-lizm w kontekstach polskich. Szkic o doświadczeniu, myśleniu i pisaniu powojennym, Warszawa 1997.

\section{Wydawnictwa ciągłe}

Bugajski L., Poezja wedtug Stachury, „Twórczość” 1676, nr 6, s. 95-96.

Grela K., Wszystko jest poezja, „Radar” 1982, nr 14, s. 14-15.

Januszkiewicz M., Od egzystencjalizmu do mistyki. O prozie Edwarda Stachury, „Pamiętnik Literacki" 1994, nr 4, s. 96-115.

Rutkowski K., Próba całości i poezja świata, „Literatura” 1976, nr 19, s. 12.

Szulc A., Życie na ostrzu noża, „Radar” 1977, nr 8, s. 14-15.

Szybist M., Uśmiechnięty Dostojewski, „Życie Literackie” 1970, nr 6, s. 6-7.

\section{Źródła internetowe}

http://sjp.pwn.pl/szukaj/absolutny.html [dostęp: 5.02.2018].

http://encyklopedia.pwn.pl/haslo/absolutyzm;3865278.html [dostęp: 5.02.2018].

https://www.youtube.com/watch?v=kzzee2Ce7HQ [dostęp: 31.05.2018]. 


\title{
Stachura's individual philosophy in his Everything is poetry
}

\begin{abstract}
Summary
This text is the presentation of Edward Stachura's philosophy. It is not about literal philosophy, however, it concerns a system of values and views taken by the writer. The article is an attempt to read Stachura from a different side than as a poet, bard, and mediocre singer. It is a compilation of the writer's various texts, but the leading one is a little-known work called Everything is poetry. The story-river (edited by H. Berezy, Z. Fedecki, K. Rutkowski, vol. 4, Warsaw 1984) Stachura transforms into almost a sage, into a philosopher who tries to create elementary definitions of the world, people, time and eternity. First of all, I analysed the conceptualisation of the phrase "everything is poetry" as well as attempting to explain what poetry is for the writer in general. The most important conclusion is that "everything is poetry and the least poetry is a poem; everyone is a poet and the least poet is a poet who writes poems". Thus, he proves that he is not only an "extreme" creator, but one who seeks hope and gaps in describing and understanding the world. Ultimately, it is also a study of Stachura's broadly understood optimism, underestimated in his work on a daily basis.
\end{abstract}

Keywords: philosophy, Edward Stachura, poetry, poet, sensitivity, human, poem, emotionality, everything 